\title{
THE VITAL PRINCIPLE OF PAUL JOSEPH BARTHEZ: THE CLASH BETWEEN MONISM AND DUALISM*
}

\author{
by
}

\section{ELIZABETH L. HAIGH**}

IN THE history of eighteenth-century medicine, the name of the Medical University of Montpellier is practically synonymous with the theory of vitalism. In its most general sense, vitalism assumes that the study of organic phenomena cannot be reduced to a branch of physics or chemistry. It affirms that the living body possesses some unique entity, a soul, force, faculty or principle which causes it to transcend the realm of inert matter. Such a view of living matter was introduced into Montpellier in the 1730s, a time when the prevailing tendency among medical theorists was to view a living body as a complex mechanism. For the remainder of the century, the teachers at that school all seem to have taught that life and non-life are absolutely separate categories of nature which must be studied with different tools.

The most influential Montpellier vitalist of all was Paul Joseph Barthez (1734 1806) who elaborated his theory in the Nouveaux éléments de la science de l'homme, a two-volume work first published in 1778. In it, he attributed the functions of a living body to the action of a force which he referred to simply as the vital principle (le principe vitale). He considered that it coexists in the body with the rational soul. The role of the latter is limited to overseeing that small proportion of body activity which is due to the will and which is conscious. The vital principle, on the other hand, governs those functions which had traditionally been assigned to the vegetative or lowest soul in the Galenic system. Though Barthez was never able to decide whether the vital principle was material or immaterial substance, he thought that all the evidence pointed to its existence separate from the matter of the body itself. Nouveaux eléments was devoted to examination of the nature and the functions of the vital principle.

The theory of the vital principle was a departure from the type of vitalism which had been evolving particularly among Barthez' older contemporaries at Montpellier. Many of the school's teachers and former students had contributed to the development of a theory concerning the vital role of the force of sensibility. That name was conferred upon a force or principle which was considered to be inherent in and inseparable from the very substance of living matter. Such a theory made living motion a function of the body itself and not the consequence of some force or substance separate from it and possessing a different nature. By the second half of the eighteenth century, various forms of the theory of sensibility were gaining prestigious adherents

\footnotetext{
-The research for this paper was supported by a grant from the Canada Council.

* Elizabeth Haigh, Ph.D., is Assistant Professor of History, Saint Mary's University, Halifax, Canada.
} 


\section{Elizabeth L. Haigh}

among physicians and medical theorists. It seemed to be confirmed by a wealth of experimental evidence and, in many respects, it was narrowing the theoretical gap which divided mechanists from the animists in the first part of the eighteenth century. Though Barthez knew well the work done in support of the thesis that life is immanent in the body, he rejected it. It is probable, he wrote, that the vital principle is not part of the matter of the body though it controls it throughout the span of its life. As long as it remains attached in some way, Barthez thought that the organism carries out its functions. It was this notion that the source of motion in a body is outside the matter of that body which put Barthez outside the mainstream of French vitalist thought in the decade of the 1770s when his major work was composed.

Barthez received his medical degree from Montpellier in 1753. In 1761 he was awarded a Chair of Medicine at that institution. The school served him and his ambitions very well. In time he achieved considerable prestige as a physician and medical theorist. In Montpellier itself, his reputation has not been surpassed to this day. ${ }^{1}$ In the eighteenth century, his theory of life and the vital principle commended itself to his colleagues and guided the work of such famous physicians as Jean Charles Grimaud and Charles Louis Dumas. Today, almost two centuries later, every physician and medical student at that school is still occasionally reminded of his contribution to medical theory and of the way it directed that university.

This paper will briefly examine the theoretical context in which vitalist notions including Barthez' theory of the vital principle were developed. It will also consider reasons why Barthez chose a theory which diverged in some significant ways from the theories of his contemporaries with respect to the question of the nature of life. I hope that it will suggest some reasons why his theory exerted such a powerful influence on his students and successors at Montpellier.

At the beginning of the eighteenth century, speculation concerning the fundamental nature of life owed a considerable debt to seventeenth-century physical science. In particular, Newton's immensely successful work in the field of physics and astronomy had dramatically demonstrated that henceforth the physical sciences were firmly rooted in a sound theoretical and methodological foundation. Understandably every student of the life sciences dreamed of achieving a similar coherence in his discipline. That impulse gave birth to theoretical systems which sought to unify the data of physiology and anatomy. It is logical that in their search for a direction, physicians and physiologists would turn to what appeared to be the more successful disciplines

\footnotetext{
${ }^{1}$ For example, one historian from Montpellier recently wrote that "Toutes les accusations portées plus tard contre le vitalisme de Barthez sont fausses. Ceux qui les ont avanctes l'ont méconnu." M. Gaston Giraud, 'Le problème de la vie', Languedoc méd., 1967, 50: 3-46. In a biographical article, another author wrote that "Aujourd'hui, personne ne conteste plus a Montpellier que Paul Joseph Barthez ait été une des plus grandes figures de l'École, bien que son renom soit aussi efficace à l'étranger . . . les idées essentielles qu'il a émisés sont devenues aujourd'hui tellement évidentes qu'elles ne sont plus contestées par personne. Seule l'histoire de la médecine est là pour rappeler qu'il n'en fut pas toujours ainsi. La gloire personnelle de Barthez y perd certainement, mais la triomphe de ses idées, n'est-ce pas l'essentiel?" Louis Dulieu, 'Paul Joseph Barthez', Rev. Hist. Sci. Applic., 1971, 24: 149-176.
} 


\section{The vital principle of Paul Joseph Barthez}

for guidance. Thus it was that very many iatromathematical and iatromechanical works appeared in the latter part of the seventeenth century. The work of Giovanni Borelli on animal motion, that of Georgius Baglivi on muscle fibres and that of Lorenzo Bellini on kidney structure and function are only a few examples of many works which attempted to understand living functions in terms of physical and mathematical principles. In every case, the underlying assumption was that the physical body is a complex mechanism which operates in accordance with the laws of matter and motion. It was assumed that willed and conscious activity derive from a rational, immaterial principle located in the brain or the soul. For at least the first third of the eighteenth century, the medical scene was dominated by Herman Boerhaave (1668-1738) of Leiden University, the most famous mechanist theorist of all. His European reputation as a theorist, teacher and physician was unsurpassed in his lifetime and his physiological system came to be a largely undisputed guide in all medical schools. The mechanists as a whole contributed substantially to the advancement of physiology. Nevertheless their particular mechanical philosophy did not go unchallenged for long.

At the same time that Boerhaave was enjoying his success and fame, Georg Ernst Stahl (1659-1734) was paving the way for a complete revision of the fundamental principles of biological thought. In a series of works written largely between 1706 and 1708, while he was on the medical faculty of the University of Halle, Stahl enunciated an animist theory of life. That is, he argued that all the functions of a body, unwilled as well as willed, unconscious as well as conscious, are the result of the activity of a soul or anima. ${ }^{2} \mathrm{He}$ intended his arguments to serve as a defiant illustration of the limitations and errors of the prevailing mechanist theory and its animal clock-work. Life, he wrote, is "the conservation of an eminently corruptible body, the faculty or force with whose aid the body is sheltered from the act of corruption."3 The body is corruptible because it is an unstable, heterogeneous mixture of elements. "If a mixture, an ordinary chemical composite, is homogeneous and stable, a living body is naturally heterogeneous and condemned to corruption if it is abandoned to itself."' It is this very heterogeneity which accounts for the great variety and complexity of living creatures. It is at the basis of all life-related functions for it enables a living organism to perform such goal-directed and integrated activities as motion, nutrition, adaptation and growth. The immaterial, rational and spiritual soul exists in a situation of mutual dependence with the material body. "The soul cannot, indeed, have any sensation of a thing, and consequently any thought or knowledge

'A thorough discussion of Stahl's physiological theory is to be found in an article by François Duchesneau, 'G. E. Stahl: antimécanisme et physiologie', Archs. Int. Hist. Sci., 1976, (in press). See also Lelland J. Rather, 'G. E. Stahl's psychological physiology', Bull. Hist. Med., 1961, 53: 37-49. Stahl's theory is discussed in the context of many larger works including Jacques Roger's, Les sciences de la vie dans la pensée francaise du XVIIIe siècle, Paris, A. Colin, 1963, pp. 427-431; and Roger K. French's, Robert Whytt, the soul and medicine, London, Wellcome Institute for the History of Medicine, 1969, pp. 117-148. Also relevant to this paper is Lester S. King's, 'Basic concepts of 18th century animism', Amer. J. Psychiat., 1967, 124: 105-110.

- Georg Ernst Stahl, Vrai theorie médicale in Oeuvres médico-philosophiques et pratiques, ed. by Théodore Blondin, 6 vols., Paris, J. B. Baillière, 1860, vol. 3, p. 43.

- Georg Ernst Stahl, Mixte et vivante, ibid., vol. 2, pp. 366-376. 


\section{Elizabeth L. Haigh}

with regard to a sensible present object without the intermediary of sensory organs; it cannot furthermore effect an act or execute its will without the aid of corporeal organs." In turn, without the soul, the body ceases to live and decomposes. ${ }^{5}$ The connexion between the material and immaterial was always a problem for those persons who believed in their relationship in one body. Like most proponents of such an idea, Stahl's discussion of the question was less than adequate.

Mechanists and animists alike considered themselves to be separated by a considerable theoretical gulf. Their differences of approach to the organism and their emphasis on different types of functions are undeniable. Both groups, however, adhered to the basic assumptions of physiological dualism. Like René Descartes who first articulated the most complete form of the body and soul, material and immaterial dualism in his Discourse on Method, Boerhaave and Stahl both considered the matter of the body to be passive material which requires the action of some external force to move it. The dualism is, of course, particularly clear in the case of Stahl and the animists.

In the 1730s, a form of Stahlian theory was introduced to Montpellier by François Boissier de Sauvages (1706-1767). His animist notions were initially supposed to have created an uproar because, like most other European medical schools, Montpellier had a mechanist orientation. In time however, antimechanist arguments prevailed and took firm root there. ${ }^{6}$

The vitalists who succeeded the animists in Montpellier and elsewhere consistently acknowledged that Stahl's anti-mechanist arguments were sound. But as eighteenthcentury physicians attempted to fit progressively more numerous observations into some theoretical framework, the inadequacy of both mechanism and vitalism became apparent. Both of the traditional dualist systems were unsatisfactory and needed to be replaced. One of Sauvages' students, Théophile de Bordeu (1722-1776), made a particularly significant contribution to vitalist theory. His medical philosophy was most clearly and completely argued in a 1752 work entitled Recherches anatomiques sur la position des glandes et leur actions. Like the mechanists he restricted the role of the soul to directing those actions which are conscious and willed. Most of the actions of a living body are not among them and he assigned those to a government by a force he called sensibility. Bordeu thought that vital function belonged to each organ so that it was not imposed from outside by a soul or other force separate from the body. His investigation of glands demonstrated the inadequacy of the mechanists' theories about this activity in terms of pore size, blood velocity, the relationships between different vessels and so on. He went on to account for glandular activity and all other vital functions in terms of a specific force of sensibility residing in each organ and a general sensibility directing the whole body. ${ }^{7}$ So vital motion came to be viewed as the result of a distinct principle inseparable from the material of the body.

\footnotetext{
- Stahl, op. cit., note 3 above, pp. 46-48. The same idea is expressed in Georg Ernst Stahl, Mécanisme et organisme, vol. 2, pp. 219-226.

-A recent biographical study is by Louis Dulieu, 'François Boissier de Sauvages (1706-1767)', Rev. Hist. Sci. Applic., 1969, 22: 303-322. Also see Lester S. King, 'Boissier de Sauvages and 18th century nosology', Bull. Hist. Med., 1966, 40: 43-51.

' Elizabeth L. Haigh, 'Vitalism, the soul and sensibility: the physiology of Theophile Bordeu', J. Hist. Med., 1976, 31 :
} 


\section{The vital principle of Paul Joseph Barthez}

Bordeu acknowledged that his ideas on sensibility owed something to the work of Jean Baptiste Van Helmont (1577-1644) and Francis Glisson (1598-1677). In fact, Bordeu's theory is the product of a marriage between vitalist convictions and monist assumptions implicit in the work of the two men. At the beginning of the seventeenth century, about the time that Descartes determined that human life was constituted of an intricate mechanism and an immaterial soul, Van Helmont conceived of the life of a substance as being immanent in that same substance. In a living body, he wrote, there is a seminal principle or archeus which constructs the body and directs its activity through a multitude of subsidiary archei. ${ }^{8}$ An immortal and spiritual soul, Van Helmont wrote, governs consciousness and intellect as well as imagination, judgement and memory, and it is centred in the brain. ${ }^{\circ}$ The significant point here is that the archei which oversee most of the functions of life were seen to be an integral part of the body which experiences that life. Van Helmont's writing is a kind of verbal labyrinth of magical, alchemical and astrological imagery. Nevertheless, it was seriously studied by physicians after him and certainly it impressed Bordeu. Where Van Helmont had written about archei under the direction of a grand archeus, Bordeu described a force of sensibility in each organ under the direction of a generalized sensibility. When the earlier system is stripped of its archaic language, the physiological base is seen to be a monist view of living matter. ${ }^{10}$

In a 1768 work entitled Tractatus de ventriculo et intestinis, Glisson argued that the basic functional unit of an organism is the fibre. Muscle tissues, tendons, nerves and organs are all constructed of these elemental fibres. The fibre possesses a property of irritability (irritabilitas) which is an ability to contract in response to some kind of stimulus and then to relax. The complete process of irritability consists of three stages. Perception (perceptio) represents the fibre's reception of a stimulus or impulse; it awakens a desire (appetitus) on the part of the fibre to react to a particular stimulus; finally motion (motus) is the execution of the required action.

According to Glisson, the vast majority of the functions of the body are governed by a basic and even primitive form of perception which he labelled a natural perception (perceptio naturalis). Occurring independently of the will, the consciousness and even the nervous system, it is entirely the product of the fibre and its organization. In addition, there is a sensual perception which is conscious and an animal perception which is conscious, deliberate and under the control of the will. ${ }^{11}$ A spiritual, immaterial soul conferred consciousness, will and rationality but not life itself.

\footnotetext{
- Jean Baptiste Van Helmont, 'The chief or master-workman', Oriatrike or physick refined, trans. by J. C. Sometime, London, Lodorvick Loyd, 1662, pp. 35-36.

- Jean Baptiste Van Helmont, 'The seat of the soul', ibid., pp. 192-197.

10 The argument that Van Helmont's theory is a monist one is put forward by Walter Pagel in 'The reaction to Aristotle in seventeenth century biological thought', Science, medicine and history. ed. by E. Ashworth Underwood, 2 vols., Oxford, Oxford University Press, 1953, vol. 1, pp. 489-509. Probably the best single source for understanding the elaborate and complex theory of Van Helmont is Walter Pagel's, 'The religious and philosophical aspects of Van Helmont's science and medicine', Bull. Hist. Med., 1944, Supplement No. 2. Other general sources are Lester S. King, The road to medical enlightenment, 1650-1695, London, MacDonald, 1970, pp. 37-62, and Jacques Roger, op. cit., note 2 above, pp. 98-103.

11 Francis Glisson, Tractatus de ventriculo et intestinis, London, H. Brome, 1677, pp. 147-170.
} 


\section{Elizabeth L. Haigh}

Glisson equated his notion of the natural perception to Van Helmont's archeus. Walter Pagel has demonstrated that their shared conviction that life is immanent in the matter of the body itself is a monism. ${ }^{12}$ This is also true of Bordeu's theory. In each case this is quite different from the dualist systems which treated matter as an inert substance unless it was acted upon by an immaterial force.

By the mid-eighteenth century, the Glissonian notion of matter became formative in medical and physiological theory. Significantly it provided physiologists with concepts which enabled them to move beyond the limitations of the mechanistanimist controversy. By the 1740s that dialectic was becoming strained in any case. While Glisson said that the process of organic activity is due to an intrinsic irritability, he wrote that in its first stage it is awakened by a perception which is to say, by a kind of sensibility. For Bordeu, irritation was a signal which awakened the active force of sensibility. Thus the notions of irritabilty and sensibility can be confused and in the case of these two physicians, they were practically interchangeable. And so the terms would remain in the writings of other medical theorists in the eighteenth century.

In 1747 in his Primae Linae or First Lines of Physiology, Albrecht von Haller (1708-1777) discussed the vis insita or a tendency to motion residing in the muscle of a living body. He wrote that "there resides in the heart a kind of impatience to stimulus.... That motion is peculiar to the heart itself; coming neither from the brain, nor the soul; seeing it remains in a dead animal even when the heart is torn out of the breast; neither can it, by any act of the will, be made either quicker or slower."13 The vis insita is "most abundant in the intestines and the heart both of which continue to contract long after they have been removed from the body. It is a widespread force and different muscles are activated by different stimuli such as the bladder by urine, the heart by blood and so on."14 Finally:

These powers (governed by a vis insita) do not arise from the will; nor are they lessened, or
excited, or suppressed, or changed by the same. No custom nor art can make these organs
subject to the will, which have their motions from a vis insita; nor can it be brought about,
that they should obey the commands of the soul, like attendants on voluntary motion. It is so
certain that motion is produced by the body alone, that we cannot even suspect any motion to
arise from a spiritual cause, besides that which we see is occasioned by the will; and, even in
that motion which is occasioned by the will, as stimulus will occasion the greatest exertions, when
the mind is very unwilling. ${ }^{15}$ This vis insita was, in fact, a kind of irritability which functioned much like Glisson's irritability and Bordeu's sensibility. In Haller's case, however, there was no tendency to confuse the two forces. Haller's use of "sensibility" was restricted to conscious sensations. In 1752, the same year that Bordeu's Glandes was published, he read

12 Walter Pagel, 'Harvey and Glisson on irritability with a note on Van Helmont', Bull. Hist. Med., 1967, 41: 497-514. See also Owsei Temkin, 'The classical roots of Glisson's doctrine of irritation', ibid., 1964, 38: 297-328.

${ }^{13}$ Albrecht von Haller, First lines of physiology, trans. from Latin and printed under the inspection of William Cullen, 2 vols. in 1, reprint of 1786 edition, New York, Johnson Reprint Co., 1966, vol. 1, pp. 59-60. The emphasis in this passage is Haller's own.

14 Ibid., p. 234.

${ }^{16}$ Albrecht von Haller, 'A dissertation on the sensible and irritable parts of animals', London, 1755. A contemporary trans. with intro. by Owsei Temkin, Bull, Hist. Med., 1936, 4: 651-699. 


\section{The vital principle of Paul Joseph Barthez}

papers 'On Sensibility' and 'On Irritability' before the Royal Society of Göttingen. In them he described what he considered the nature of the two forces to be. He found that the most sensible organs are the least irritable ones. Though Haller and Bordeu used the term sensibility in a quite different sense, the quarrelsome Haller criticized Bordeu's work on Glandes largely because, in his own experiments, he had not found these organs to possess obvious sensitivity to painful stimuli.

Particularly galling to the pious Haller was the work of the notorious libertine Julien Offray de La Mettrie (1709-1751) who outraged Europe with l'Homme machine which appeared in 1747. With characteristic perversity, he dedicated the work to Haller. Its thesis was that neither soul, nor mind, nor special vital forces exist as unique entities. All the phenomena of the body including those normally attributed to will or to intelligence are merely consequences of physical organization. The distinction between inert nature and the living organism is to be found in the phenomena of irritability which La Mettrie conceived of as a general property of living substance. The work has, in the past, been described as Cartesian philosophy stripped of its soul. In fact, La Mettrie's position was nearer to that of Glisson, Bordeu and Haller. He removed the rational, conscious soul from matter and extended their conceptions of active matter to include intellectual and conscious activity. He summarized his position as follows:

all the faculties of the soul depend on the proper organization of the brain and of the body so that they are visibly nothing but organization ... the soul, therefore, is merely a vain term about which no one has any idea and for which a good intellect can only serve to name the part of us which thinks. Granting the lesser principle of motion, animated bodies have everything necessary for them to move, to sense, to think, to be contrite, and in a word, to behave itself in the material body and in the mental faculties which depend upon it. ${ }^{16}$

Everything derives from this irritability which is "an innate force ... All the vital, animal, natural and automatic motions are the result of this action."17

The conceptions of La Mettrie and those of the Montpellier vitalists, particularly Bordeu, were developed in the work of the Encyclopedist Denis Diderot (1713-1784). Though not a physician, Diderot was intrigued with the question of the nature of life. Over the years he elaborated a materialistic theory of life designed to answer the question of how insensible matter comes to be absorbed by the body of an animal and thus becomes alive and sensible. The solution posed in Entretien entre d'Alembert et Diderot and Rêve de d'Alembert composed in 1769 was very similar to La Mettrie's solution in l'Homme machine. Diderot said there is a latent force of sensibility in all the material in the universe. Among other vitalists, the assumption was that the properties of life are added on to dead matter and they supersede the inorganic properties. But Diderot saw life as a condition in which barriers are actually removed from inorganic matter. He wrote that "from inert matter and given heat and motion, there results the faculty of sensation, life, memory, consciousness, passion and thought."18 It was a visionary concept. He thought that life is continually emerging

16 Julien Offray de la Mettrie, l'Homme machine, ed. by Aram Vartanian, Princeton, Princeton University Press, 1960, p. 180.

${ }^{17}$ Ibid., pp. 196-197.

18 Denis Diderot Le rêve de d'Alembert, in Oeuvres complètes, 15 vols., Paris, Le Club Français, 1969 , vol. 8, pp. 67-69. 


\section{Elizabeth L. Haigh}

from its potential state so that soil, stone, plants and animals form an intricate and interconnected mass of continually changing matter in which neither birth nor death have any ultimate meaning.

Without question there is a great distance in time and theory between Van Helmont's archeus and Diderot's sensibility. Nevertheless both men believed that life is immanent in the matter of the organized body. As Pagel has pointed out, if one does not separate the life impulse from organic matter, then the soul or some other outside force is not required to account for vital activity. That is in contrast to dualist systems which treat matter as an aggregate of inert particles requiring an external force to move them and to preserve them from decay if they are organized. ${ }^{19}$ Thus it is that when Bordeu and his colleagues did their work on sensibility, they were basically replacing the animists' dualist conceptions with monist ones at Montpellier.

\section{II}

In 1772, as a teacher at Montpellier, Barthez pronounced a discourse on the subject of the vital principle. He believed that it was a new and unifying concept which would revolutionize physiological theory. Six years later, Nouveaux éléments de la science de l'homme expanded on the subject of the vital principle. In time Barthez' colleagues at Montpellier came to agree with his evaluation of the importance of his notion so that his theory of vitalism eclipsed that of Bordeu and others. It also wiped out the last vestiges of animism which still remained at Montpellier.

Barthez did not share Bordeu's admiration for Van Helmont whom he described as "having been involved with meditations approaching deliria." He dismissed Bordeu's specific organic sensibilities as a vain multiplication of causes for the purpose of explaining the functions of life. Barthez thought that all the functions which Bordeu and others had assigned to a multitude of organic sensibilities could be more accurately attributed to the faculties of his single vital principle. He treated it as the cause of all physiological motion and put it on a par with such physical principles as attraction and gravitation. ${ }^{20}$ The vital principle was made up of sensitive and motor components and it was assumed to coexist in the body with the rational soul. For the most part it governed that numerous and complex host of largely unconscious and unwilled activity which constitutes the majority of organic phenomena.

For the purpose of this paper, it is significant to note that Barthez considered it probable that the vital principle has an existence separate from that of the body it animates. The most important reason for that assumption derived from his view that matter is fundamentally inert substance. He wrote that "The principle of movement and feeling in the living man cannot be understood as a modification of the body: at least not if one does not reject accepted ideas which give, as essential qualities of matter, extension which is exclusive of all perception and inertia which prevents its spontaneous motion however mobile it may be."21 Such a view was incompatible

10 Pagel, op. cit., notes 10 and 12 above.

${ }^{20}$ Paul Joseph Barthez, 'Discours préliminaire', Nouveaux éléments de la science de l'homme, Montpellier, J. Martel ainé, 1778, pp. iii-xi.

21 Ibid., p. 28. 


\section{The vital principle of Paul Joseph Barthez}

with the monist theses of Van Helmont, Glisson, Bordeu, Haller, La Mettrie, Diderot and others. In support of his viewpoint, Barthez remarked that the vital principle can be destroyed with no apparent alteration of the integrity of the body. For example, though a drowned man has all his physical parts intact, he can never move again because the vital principle has either left the body or been destroyed. On the other hand, the vital principle can survive a long time even with very substantial lesions of some essential organs like the heart and brain. For such reasons Barthez believed it likely that the cause of living functions is separate from the matter of the living body. ${ }^{22}$ It is imposed by a principle which maintains life only so long as its link with that body is not broken. When the inevitable separation finally occurs at death, the body reverts to an inactive inert mass of matter which becomes subject to dissolution and decay. Therefore I think it is legitimate to see Barthez as, in certain respects, more akin theoretically to the dualists than to the monists, even though he rejected the details of both the mechanists' and animists' systems.

Barthez' arguments on behalf of his physiological theory appealed to Newtonian principles of empiricism and scientific explanation. Barthez lived for a time in Paris where he was a close friend of Jean d'Alembert who was co-editor of the Encyclopédie and a major exponent of the Newtonian philosophy. In the preliminary discourse to his Nouveaux éléments, Barthez alluded to the Newtonian influence in his own work. The object of natural philosophy, he wrote, is research into the causes of nature. The observer can only study the succession of phenomena and discern a series of causes from it. These experimental causes have been variously assigned such indeterminate labels as Powers, Principles, Forces, Faculties and so on. Barthez was impressed with astronomy. He thought it had achieved progress because an immense variety of effects observed in celestial physics had been assigned to a small number of experimental causes. As the science progressed, the number of experimental causes diminished with the establishment of still more general laws to incorporate the succession of analogous phenomena. He speculated that, even though physicists regarded magnetism and electricity as two distinct causes, it was probable that in time they would be united under a third cause which produces all their effects by different modifications. This search for more and more general causes constituted the essence of what he considered to be "the good philosophic method" (la bonne méthode de Philosopher). The ancients had erred in being too apt to multiply causes. Many of Barthez' contemporaries, on the other hand, went too far in trying to diminish the number of causes in natural science below that which observation indicates. This was an error made by both mechanists and animists. The former tried to reduce complex motor functions of animals to the single force of communication of motion by impulsion which acts in inorganic nature while the latter tried to relate all action to a rational soul.

Barthez warned his readers against the solidists whose viewpoint was gaining ground. They were too apt to multiply causes. Its members rejected both the mechanists' and vitalists' assumptions and some of them appeared to attach great importance to the ideas of Van Helmont, particularly to his notion that each organ has its own life in addition to a separate life of the whole body. Barthez dismissed

28 Ibid., pp. 27-41. 


\section{Elizabeth L. Haigh}

archée, the seeds, the sensitive soul and other such concepts as "fictions" and a vain multiplication of occult causes. Their methods are as imperfect as those of the mechanists. We recognize, in this discussion, those persons including Bordeu who made physiology dependent upon sensibility, irritability or some innate force in the fibres of the body. ${ }^{23}$

Barthez used the word "principle" in general to designate the experimental causes of the phenomena of motion. He thought that the motive forces of nature occupy a scale from the most simple principles of motion to the principles of life which conserve the organized bodies of plants and animals. The first and most simple one proper to matter is impulsion. The force of attraction is more complex and is responsible for gravity, for the formation of mixed and composite bodies by particular affinities and for the phenomena of magnetism and electricity. Still more complex forces are involved in the formation of ice crystals, crystalline salts and other angular bodies. The highest and most complex of all principles in this hierarchy is the vital principle of plants and animals. It is responsible for living functions which cannot be explained by the laws of statics, hydraulics or chemistry. The vital principle varies in complexity beginning with plants and terminating with man whose organs are the most perfect and who is the most intelligent of all living things. ${ }^{24}$

So Barthez treated the vital principle as the most general of experimental causes. $\mathrm{He}$ assumed that it coexists with the rational soul. The respective functions of the soul and the vital principle as well and their inter-relationship were the subject of the Nouveaux éléments. ${ }^{25}$

Since Barthez was clearly uneasy with the notion that living activity can reside in the body parts themselves, why did he not choose the animist solution to the question of living matter? Like other vitalists, he considered that the animists had accomplished a very important task when they demonstrated the inadequacy of mechanist physiological principles. Nevertheless, he wrote, the animist notions of the functions of the soul cannot account for living phenomena. For Barthez the notion of the soul was inextricably tied to the will and to rationality. The animists had required the soul to participate in unconscious activity, but Barthez dismissed this pointing out that the soul has no sense of the body's internal motions. Neither can it modify them. For example, the motion of the heart and arteries cannot be altered by an act of the will. Animists had dealt with this by dividing the soul into various faculties overseeing different functions. Barthez believed that the soul is a unity (un être simple) and he was unwilling so to divide it. The conviction about a united and presumably indivisible soul could not reconcile the animists' position to the common observation that parts separated from the body can often continue to move and to respond to stimuli. How, for example, can one explain a heart beating after it has been removed from the body and its association with the soul? Even in a recently decapitated man there were motions in both the head and the body. What then of the soul's government? Barthez left it to attend to the rational and conscious functions and assigned

22 Ibid., pp. xi-xviii.

24 Ibid., pp. 1-6.

${ }^{25}$ For a good discussion of Barthez' view about the nature of the vital principle, see Réjane Bernier, 'La notion de principe vitale de Barthez', Archs. Phil., 1975, 35: 423-441. 


\section{The vital principle of Paul Joseph Barthez}

the remainder of the body's activity to the vital principle. ${ }^{28}$

The question then was what is the nature and situation of that vital principle? If that extirpated beating heart is not explained in terms of the soul or an organic sensibility, it remained that some portion of the vital principle must reside in it. Thus, since the soul is a unity and indivisible, Barthez had to postulate a divisible vital principle. He thought that the vital principle exists in solid and fluid parts of the body alike and that it is endowed with sensitive and motor forces. One must distinguish between them, he wrote, for they produce entirely different results and exist in very different proportions of activity in the various organs. He seems to have been in agreement with Haller on that point. Like Haller he pointed out that the major organs of sensibility are the brain and nerves which possess a very feeble mobility. Unlike Haller, however, he believed that there is a relationship between the two forces such that irritability depends on sensibility. Extirpated parts continue to have mobility because some of the vital principle remains with them and "this part, when these members are irritated, is caused to move by the sentiment it has of an irritation."27 This assertion took Barthez perilously close to the position of Glisson and Bordeu. In fact, he wrote of the sensibility proper to each organ which exists apart from the nerves and is particularly clear in the case of certain small animals such as shellfish which have a sensibility though they appear to have no nerves at all. Barthez was clearly annoyed at a statement of Haller's in his Elementa physiologiae in which he wrote that Barthez had confused irritability with sensibility. He countered with the charge that Haller's assertion was based on the false assumption that all feeling is attached to the soul. ${ }^{28}$ Barthez went on to write about mobility pointing out that it weakens in proportion to the solidity of a part. In such structures as bones, the motor forces exist only to provide nourishment to the parts and to effect regeneration if the bones are broken. The fluids of body are in continual motion as a consequence of this principle. ${ }^{29}$ Indeed he argued that it is the action of the vital principle to agitate solids and fluids which action produces and maintains a suitable degree of heat. ${ }^{30}$ His assertions about the faculties of sensibility and mobility suggest that Barthez could easily have been reconciled to the "solidist" arguments which made life immanent in matter. Nevertheless, he located these forces in the vital principle and separated them from the matter of the body.

Barthez observed that muscular motion is extinguished soon after nervous connexions to it are severed or when the veins and arteries are ligatured. But it is not so with all organs. Intestinal movements continue for hours after death; a heart removed from an animal retains a strong irritability. It must be, he postulated, because these latter organs have a great deal of the vital principle and are less dependent upon sympathetic connexions with other organs. He tied this alleged quantity of vital principle to the phenomenon of sleep by reasoning that it is the organs with a greater proportion of vitality which require least rest. Sleep, he thought, is the repose

${ }^{20}$ Barthez, op. cit., note 20 above, pp. 28-35.

27 Ibid., p. 46.

28 Ibid., pp. 42-63.

20 Ibid., pp. 64-117.

${ }^{30}$ Ibid., pp. 118-141. 


\section{Elizabeth L. Haigh}

of muscle movements and it is produced by alterations in the brain which is the principal centre of these forces. But the heart, arteries, respiratory muscles, stomach and intestines keep up their motion even when the rest of the body is asleep. Since the continuous activity of these organs is necessary for life, the action of their vital principle is stronger. ${ }^{31}$ This speculation about the nature of organs which rest and those which do not was to be developed further at Montpellier by Grimaud. At the end of the eighteenth century, Xavier Bichat adopted the distinction and made it the basis for his division of living functions into animal and organic categories. ${ }^{32}$

Barthez wrote at length about sympathies, that is, about the connexions which the forces of the vital principle make between the various organs of a living body. Because of its complicated network of sympathies the body is an integrated unit. Some examples of sympathies are voice changes in puberty in response to changes in sexual organs; abscess of the liver which frequently follows a wound in the head; inflammation in one eye which produces the same symptoms in the other; if the pupil of one eye responds to light, the other will follow suit and so on. Sympathies, Barthez wrote, travel by way of nervous pathways and there is a perpetual and reciprocal communication of the tonic forces of the nerves or a constant antagonism which keeps these forces in equilibrium. ${ }^{28}$

These considerations, like those on sensibility and mobility, could just as well serve as evidence for the "solidist" position. After all, if the vital principle is variously distributed through all the parts of the body and remains even in an extirpated part, why not suppose that it is attached to matter itself? As evidence for his conviction that the vital principle has an existence separate from the body, he offered the previously mentioned examples of the drowned man and the one with the lesions of the heart and brain. He also discussed what he called the "pre-established harmony" which exists between the vital principle and motions in relation to organs which do not even exist. For example, a little bird without a mother to imitate will make flapping motions when its wings are too feeble to support it. A small calf will butt with non-existent horns. Such examples, Barthez thought, point to the probability that the vital principle is not a simple modality of the living man but has a separate existence. ${ }^{24}$

If the vital principle is separate from the matter of the body but distributed throughout all the parts, how does it act? Again Barthez seems to have approached uncomfortably near to the solidist position in dealing with this question. At one point he speculated that it must act on the molecules, that is to say, on the smallest parts of the muscle fibres to disperse them or to bring them together. ${ }^{36}$ In this case, it appears that the only really substantial point which separated Barthez from many of his contemporaries was his allegiance to the assumption that matter by nature is separate from its motive principle. Therefore life is separate from matter.

Barthez consistently maintained, however, that the nature of the vital principle

21 Ibid., pp. 227-244.

"2 Elizabeth Haigh, 'The roots of the vitalism of Xavier Bichat', Bull. Hist. Med., 1975, 49: 72-86.

2 Barthez, op. cit., note 20 above, pp. 142-172.

* Ibid., pp. 35-41.

as Ibid., pp. 68-82. 


\section{The vital principle of Paul Joseph Barthez}

could only be a hypothesis. He dismissed the possibility that it might be a substance intermediate in nature between the material body and the immaterial soul. The traditional notion of animal spirits was that they have a very fine material nature and that they use the nerves to effect a connexion between the body and soul. But Barthez left the question of whether the vital principle might be material. As one author pointed out, many of Barthez' notions about the vital principle were only consistent with its being a physical entity. ${ }^{36} \mathrm{He}$ thought, for example, that the vital principle exists in a latent or concentrated state in pupae, in seeds and in birds' eggs where it awaits animal heat to form and give life to an organism. He wrote in various places of lesions of the vital principle and of poisons acting to destroy it. How can one concentrate, produce lesions in or poison an immaterial principle? At the end of Nouveaux éléments, he wrote about death which he defined as the irrevocable cessation of sensibility and the vital motions. He wrote the following about the vital principle:

If this Principle is only a faculty united to the living body, it is certain that it perishes with the body. If it is a being distinct from the body and the soul, it may perish outside the extinction of its forces in the bodies which it animates; but it may also pass into other human bodies and vivify them ... It is possible that the end of the vital principle is related to its origin. Thus, in supposing that it may have emanated from a principle which God created to animate the worlds, it may be rejoined to the Universal Principle at death ... Whatever the destiny of the vital principle of man is at death, when his body returns to the earth, his soul returns to God who gave it to him and who assures him an immortal duration."7

With many of his contemporaries Barthez shared a conviction that medicine needed a unifying principle into which existing knowledge could be fitted and upon which subsequent observation and experimentation could be based. For him and for his successors and students at Montpellier, the vital principle served just such a purpose. He compared its "discovery" to Newton's discovery of universal gravitation. Barthez was quite convinced that the vital principle as he described it was unique and that it distinguished his system from all previous ones. It is not difficult for us to recognize that Barthez' theory of the vital principle does not belong on the same ontological plane as Newton's theory of universal gravitation. In fact, Newton would probably have dismissed the vital principle assigning it to the rubbish heap of scientific hypotheses. Sixty-five years after Nouveaux éléments first appeared, the naturalist Georges Cuvier, who claimed profound respect for Barthez, pointed out the difficulties attached to postulating the existence of the vital principle. He wrote that gravity was defined precisely in terms of its effects and connexions, and the motion of bodies towards each other is due to a specific law. The vital principle, on the other hand, was described only in the most general terms. Cuvier questioned the validity of postulating this system which was neither material nor immaterial, neither mechanical nor intelligent. To say that the phenomena of muscular contraction, sensibility, curing of wounds, formation of the foetus, reproduction of the species are all effects of a simple, single principle is merely to enumerate phenomena but not to explain

* Bernier, op. cit., note 25 above.

27 Barthez, op. cit., note 20 above, pp. 347-348. 


\section{Elizabeth L. Haigh}

them. ${ }^{38}$ Though we must concur with Cuvier's criticisms, it is interesting that most of them seem not to have occurred to Barthez' contemporaries. It is important not to lose sight of the intellectual authority which Barthez wielded especially in Montpellier.

It is significant that in the last quarter of the eighteenth century, Barthez was still searching for a transcendent cause of vital motion. Because of his own particular understanding of Newtonian principles, he wanted it to be as universal in its effects as gravity and a principle created by God to animate the world. Whatever subsequent evaluations of his work might have been, Barthez believed that he was offering medicine a completely new concept in the form of the vital principle and it was his conviction that his work would produce a revolution in medical theory as profound as the earlier revolution had been in physics.

\section{SUMMARY}

In 1778 Paul Joseph Barthez, the occupant of a Chair of Medicine at the University of Montpellier, published a book in which he argued that a living body is a composite of matter, a spiritual and rational soul and a vital principle. The latter, he wrote, governs those physiological functions which are neither willed nor conscious. The vital principle is distributed throughout all the body parts and it incorporates the faculties of sensibility and mobility.

By postulating such a vital principle, Barthez was turning his back on a considerable amount of work which had been done in support of vitalist theory especially since the mid-eighteenth century. By borrowing ideas from such seventeenth-century physicians as Jean Baptiste Van Helmont and Francis Glisson, Barthez' fellow physicians articulated theses on behalf of the theory that such forces as sensibility and irritability or mobility are located in the matter of the body itself. Théophile Bordeu and some Montpellier physicians had made physiological activity the function of a force of sensibility which is located in all the organs and body parts. Albrecht von Haller had written of a vis insita which is a kind of irritability produced by the body alone. Julien Offray de La Mettrie and Denis Diderot wrote of an irritability and a sensibility respectively. In all cases, the vital force was considered to be immanent in the matter of the body.

Barthez did not accept the notion that matter could be self-moving so he postulated a vital principle which was separate from the matter of the body. He thought it might emanate from a universal principle which God had created to animate the world. This fundamental difference of opinion about the cause of living phenomena between Barthez and many of his contemporaries sprang from a clash between a dualist conception whereby nature is divided into material and immaterial elements and a monist conception that the ability to move and feel is immanent in matter. Though we tend to evaluate the latter notion as more progressvie, Barthez' vital principle captured the allegiance of many persons such that today he is still recalled at Montpellier as the most important and influential of all vitalist theorists.

\footnotetext{
"Georges Cuvier, 'De Barthez, de Medicus, de Deseze, de Cabanis, de Darwin et de leurs ouvrages', Histoire des sciences naturelles, 5 vols., Paris, Fortin, Masson, 1845, vol. 4, pp. $27-46$.
} 